\title{
KS. PROF. JÓZEF WOLIŃSKI: CURRICULUM VITAE
}

Ks. Józef Woliński urodził się 20 września 1933 r. w Verdun (Meuse) we Francji, w rodzinie Ignacego Wolińskiego i Teodory z domu Skrabas. Jego ojciec pochodził z Nowodworu w województwie lubelskim, matka zaś pochodziła z Rasciunai niedaleko Wilna na Litwie. Ma młodszego brata Zygmunta, który jest ojcem pięciu synów.

Rodzice J. Wolińskiego przyjechali do Francji w poszukiwaniu pracy w ramach wielkiej emigracji o charakterze ekonomicznym, która miała miejsce w latach trzydziestych XX wieku. Ojciec J. Wolińskiego początkowo był pracownikiem w odlewni w Pont-à-Mousson (Meurthe-et-Moselle), natomiast matka pracowała w gospodarstwie rolnym. Po ślubie osiedlili się w Brévilly, w pobliżu Sedan w departamencie Ardeny w diecezji Reims.

W październiku 1945 r. J. Woliński wstąpił do Niższego Seminarium Duchownego w Reims. Wkrótce, w roku 1948, w ramach wielkiego powrotu Polaków z Francji do Polski, jego rodzina powróciła do Ojczyzny, jednak nastoletni Józef już w lutym 1949 r. sam powrócił do Reims, aby dokończyć naukę w szkole średniej. Po ukończeniu edukacji w niższym seminarium, w październiku 1952 r. J. Woliński wstapi do Wyższego Seminarium Duchownego w Reims.

Pod koniec studiów seminaryjnych, w 1959 r., pojawiło się pytanie dotyczące przyszłości kleryka Józefa Wolińskiego i ewentualnego powrotu do Polski, gdzie przebywali jego rodzice i brat Zygmunt. W związku z tym, że w owym czasie diecezja Reims posiadała wielu księży, z których ok. czterdziestu pracowało poza jej granicami w różnych częściach świata, Arcybiskup Reims Louis Augustin Marmottin (1875-1960), po zasięgnięciu opinii rady seminaryjnej wraz z ówczesnym rektorem Wyższego Seminarium ks. Paulem Adamem, wyraził zgodę na to, by kleryk Woliński opuścił diecezję Reims i powrócił do Polski. Zatem w lutym 1959 r., kleryk Woliński wstapił do Polskiego Seminarium w Paryżu (5, rue des Irlandais), aby dokończyć studia, a następnie powrócić do Polski.

Święcenia kapłańskie przyjął 2 sierpnia 1959 r., w Archikatedrze Warszawskiej p.w. św. Jana $\mathrm{z}$ rąk Jego Eminencji Kardynała Stefana Wyszyńskiego i tym samym został inkardynowany do Archidiecezji Warszawskiej. Po święceniach ks. Woliński nie pozostał jednak w Polsce, gdyż znalazł się w grupie pięciu księży, których Kardynał Wyszyński wysłał na studia teologiczne w Instytucie Katolickim w Paryżu. Tym sposobem powrócił do Francji. W czasie studiów w Instytucie Katolickim ks. Woliński uzyskał licencjat z teologii, a następnie rozpoczął pracę nad rozprawą doktorska, 
która przygotowywał pod kierunkiem ks. prof. Paula Henri'ego SJ, znanego wydawcy Ennead Plotyna, na temat: Pochodzenie Ducha Świętego wedlug listów do Serapiona Atanazego z Aleksandrii (La procession du Saint-Esprit d'après les Lettres à Sérapion d'Athanase d'Alexandrie), którą obronił 18 czerwca 1968 roku.

W roku 1968 Kardynał Stefan Wyszyński zaproponował ks. Józefowi Wolińskiemu, aby objął funkcję ojca duchownego w Polskim Seminarium w Paryżu, gdyż dotychczasowy ojciec duchowny - ks. Jan Wolniak (19122000), dawny więzień obozu w Dachau - przeszedł na emeryturę.

Również w roku 1968 prof. Jean Daniélou SJ, ówczesny dziekan Wydziału Teologicznego w Instytucie Katolickim w Paryżu, powierzył mu - za zgodą Prymasa Polski - funkcję asystenta prof. Borysa Bobrinskoy’a prowadzącego wykłady na temat eklezjologii prawosławnej. Szczególnym zadaniem powierzonym nowemu asystentowi było ożywienie seminarium naukowego z eklezjologii. W ramach przemian, które nastapiły w roku 1968, odnowiono sposób prowadzenia seminariów naukowych. Do tego czasu seminarium naukowe polegało na prowadzeniu w małej grupie wykładu specjalistycznego przez profesora, zaś w czasie przemian seminaria przekształcono w prawdziwe warsztaty pracy naukowej. W kontekście „wiosny 1968 roku”, korzystając z nagle pojawiających się możliwości powielania tekstów, ks. Józef Woliński zapoczątkował pracę ze studentami nad tekstami źródłowymi. Był on przygotowany do realizacji tej ,nowej formy” edukacji przez P. Henry'ego SJ, który zachęcił go do pracy na tekstach źródłowych. Jak sam opowiada, „były one napisane na woskówkach, powielane, układane, rozdawane... Jeździłem rowerem do zakładu, gdzie powielano teksty, a potem razem z klerykami z Polskiego Seminarium układaliśmy je odpowiednio".

Ks. Woliński stopniowo doskonalił swój warsztat naukowy i metody dydaktyczne, które wykorzystywał w procesie nauczania w Instytucie Katolickim stając się coraz bardziej doświadczonym nauczycielem akademickim. Gdy prof. Charles Kannengiesser SJ, następca Kardynała J. Daniélou, wyjechał z Francji do USA, ks. Woliński został zatrudniony jako jego następca. W czerwcu 1983 r. został mianowany profesorem pierwszej klasy Instytutu Katolickiego w Paryżu. Od tego czasu, razem z ks. Piotrem Ratajczakiem (1922-2012) rektorem Polskiego Seminarium w Paryżu w latach 1982-1998 - pracował nad ożywianiem kontaktów pomiędzy Instytutem Katolickim a Polską. Ich wysiłki pobudziły zainteresowanie Polską i zaowocowały podjęciem współpracy; w tym okresie udało się im uzyskać coroczne przyznawanie 13 stypendiów państwowych przeznaczonych na studia teologiczne dla studentów przybyłych z Polski (w tym czasie ze stypendiów skorzystało również kilku studentów z innych krajów Europy Środkowowschodniej). Przyznawania stypendiów zaprzestano po uzyskaniu przez Polskę pełnej niepodległości.

30 czerwca 2001 r. ks. Woliński zakończył pracę w Instytucie Katolickim w Paryżu i przeszedł na emeryturę. 8 stycznia 2002 r. odbyło się w Instytucie 
Katolickim uroczyste pożegnanie ks. prof. Józefa Wolińskiego. Według zwyczaju Profesor wygłosił wykład, w którym przedstawił zasadnicze punkty swoich badan teologicznych. Temat wykładu brzmiał: Le paradoxe chrétien avant et après Nicée (325). Natomiast nieco później, w dniach 5-6 lutego 2002 r., z inicjatywy ks. prof. Henri-Jérôme Gagey oraz s. prof. Geneviève Médevielle, zorganizowano w Instytucie Katolickim specjalną sesję naukową mająca na celu podsumowania pracy naukowej ks. prof. Józefa Wolińskiego oraz prof. Michel Corbin SJ - kolegi i serdecznego przyjaciela ks. Wolińskiego. Materiały z tej sesji zostały opublikowane w tomie pod tytułem De commencement en commencement. Le renouveau patristique dans la théologie contemporaine (Paris 2007, ss. 344).

Od października 2002 r. do końca pierwszego semestru roku akademickiego 2014/2015, czyli do początku roku 2015, ks. Woliński prowadził wykłady z teologii patrystycznej w tzw. „Szkole Katedralnej” (École Cathédrale) - Collège des Bernardins - założonej przez Arcybiskupa Paryża, Kardynała Jean-Marie Lustigera, w słynnym budynku z XIII w., niedaleko katedry NotreDame, odrestaurowanym w 2009 roku.

Ks. prof. Woliński przez ponad 30 lat wykładał patrologię w Instytucie Katolickim w Paryżu. Prowadził prace licencjackie i doktorskie. Uczestniczył jako prelegent w wielu sympozjach naukowych, we Francji, w Rzymie, w Oxfordzie. Prowadził też okolicznościowe wykłady w PWT i ATK w Warszawie. Jest też członkiem wielu towarzystw naukowych m.in. Association Internationale d'Études Patristiques.

$\mathrm{Na}$ wniosek Jego Eminencji Kardynała Kazimierza Nycza, Arcybiskupa Metropolity Warszawskiego z dnia 7 września 2009 r., Papież Benedykt XVI mianował ks. prof. Józefa Wolińskiego prałatem Jego Świątobliwości, a oznakę tejże godności wręczył mu dnia 14 lutego 2009 r. w Polskim Seminarium w Paryżu bp prof. Stanisław Budzik - ówczesny Sekretarz Generalny Konferencji Episkopatu Polski. Ks. prof. Woliński otrzymał także tytuł „,professeur honoraire", przyznawany we Francji wykładowcom, którzy szczególnie zasłużyli się w dziedzinie dydaktycznej i naukowej.

Obecnie ks. Woliński mieszka w Polskim Seminarium, które w 1997 roku zostało przeniesione z Paryża (5, rue des Irlandais, w piątej dzielnicy, przy słynnym gmachu „le Panthéon”) do Issy-les-Moulineaux (11, rue Jules Guesde) miejscowości położonej przy południowo-zachodniej granicy Paryża. Ciagle jest bardzo aktywny. Służy księżom pomocą duchową i językową, prowadzi różne wykłady i konferencje na tematy patrystyczne, a także dni skupienia i rekolekcje dla różnych grup w Paryżu oraz w innych miastach Francji.

Ks. Piotr Szczur - Lublin, KUL 
